\title{
Impact of Proteins on Aggregation Kinetics and Adsorption Ability of Hematite Nanoparticles in Aqueous Dispersions
}

Anxu Sheng, Feng Liu, Nan Xie, Juan Liu*

School of Environmental Sciences and Engineering, Peking University, Beijing, China, 100871

Corresponding Author:

*Phone: (+86)010-62754292-808; email: juan.liu@pku.edu.cn

11 pages

2 Sections

1 Table

6 Figures 


\section{Section S1. Hematite synthesis:}

2 The hematite nanoparticles were synthesized by slowly dripping $80 \mathrm{~mL}$ of $1 \mathrm{M}$ ferric nitrate

3 solution at the speed of $0.5 \mathrm{~mL} / \mathrm{min}$ into $1 \mathrm{~L}$ of boiling distilled MilliQ water while stirring

4 vigorously. After the dripping was finished, the resulting suspension was removed from the heat

5 and cooled overnight. The suspension was then dialyzed in standard grade Cellulose dialysis

6 membranes (1000 MWCO, Spectra Por) against MilliQ water until the conductivity remained

7 constant. The synthetic NPs were stored in suspensions at $4{ }^{\circ} \mathrm{C}$ in dark.

8 
Section S2. Solution Chemistry:

The electrolyte $\left(\mathrm{NaCl}\right.$ and $\left.\mathrm{CaCl}_{2}\right)$ stock solutions were prepared and filtered through $0.2 \mu \mathrm{m}$ syringe filters just before use. The concentrations of electrolytes in stock solutions were measured by ICP-OES. BSA (A7906) and Cyt (C2037) were obtained from Sigma-Aldrich in powder form and used as received. Protein concentration of the protein stock solution was determined by measuring the absorbance at $550 \mathrm{~nm}$ (extinction coefficient $\mathrm{E}^{\mathrm{mM}}=8.4$ ) for Cyt and at $380 \mathrm{~nm}$ (extinction coefficient $\mathrm{E}^{\mathrm{mM}}=43.8$ ) using a Agilent Cary 300 spectrophotometer. No measurable protein aggregates was observed by DLS in $8 \mathrm{mg} / \mathrm{L}$ BSA or Cyt solutions at $\mathrm{pH} 5.7$ or 9 . The $\mathrm{pH}$ 5.7 and $\mathrm{pH} 9$ stock solutions were prepared from MiliQ water and then the $\mathrm{pH}$ was adjusted to the desired $\mathrm{pH}$ using a concentrated $\mathrm{NaOH}$ or $\mathrm{HCl}$ solution. The $\mathrm{pH}$ values of the stock solutions were checked and adjusted just before use.

(1)


Table S1. The properties of the synthetic hematite NPs and proteins used in this study.

31

\begin{tabular}{|l|l|l|l|}
\hline & Size & $\mathrm{pH}_{\text {iep }}$ & Molecular weight \\
& & & $(\mathrm{g} / \mathrm{mol})$ \\
\hline Hematite & $9 \pm 2 \mathrm{~nm}$ & $7.2-9.5^{1}$ & 159.7 \\
\hline BSA & $5.5 \times 5.5 \times 9 \mathrm{~nm}^{2}$ & $4.51-4.76^{3}$ & $66430^{2}$ \\
\hline Cyt & $3 \times 3.4 \times 3.4 \mathrm{~nm}^{4}$ & $10.37^{5}$ & $12230^{4}$ \\
\hline
\end{tabular}

32

33

34

35

36

37

38 
39

40

41

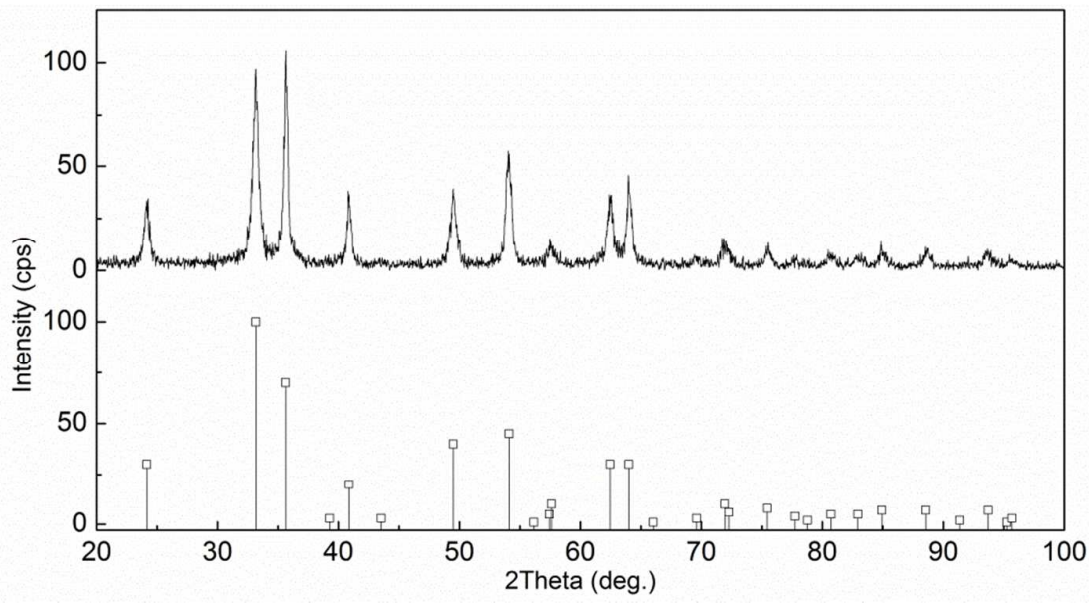

Figure S1 XRD pattern of synthetic NPs (above) with hematite reference (below, JCPDS No. 33-0664) 

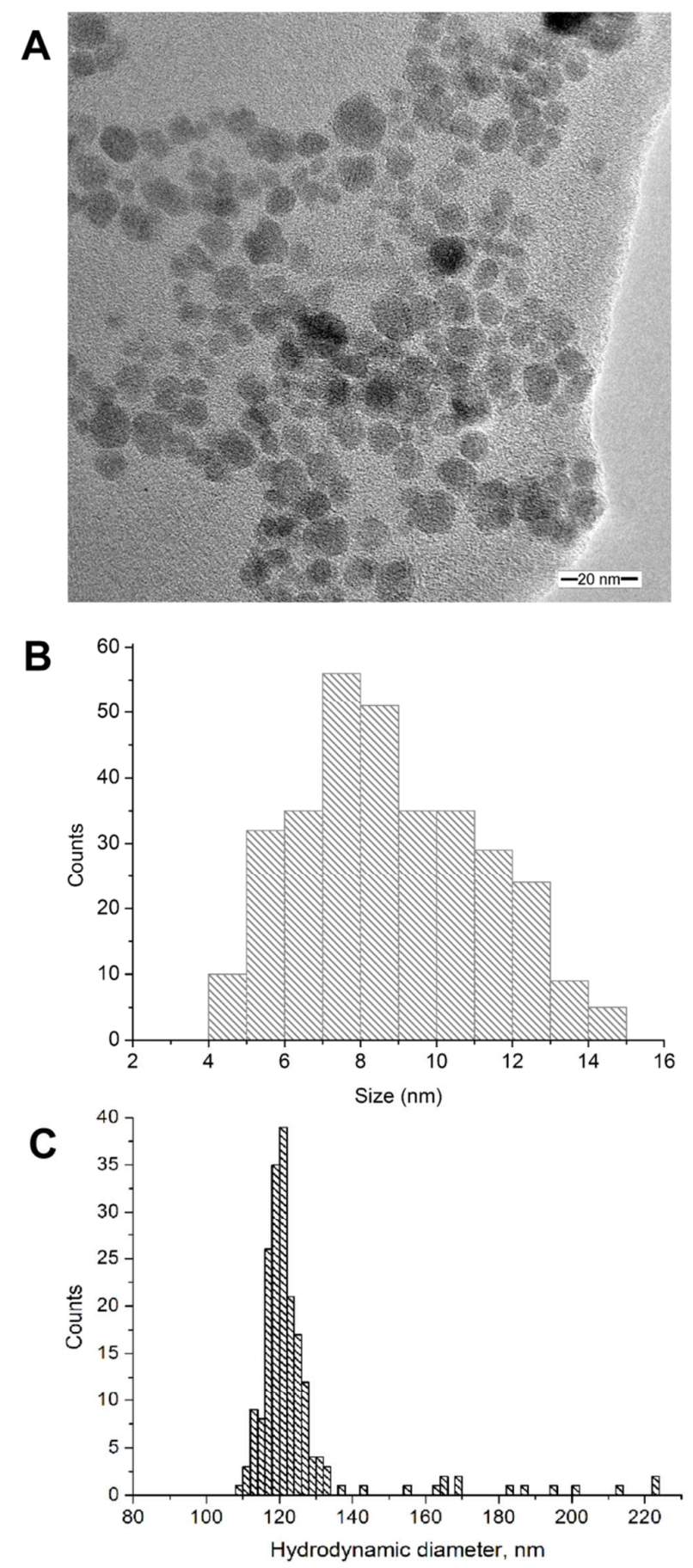

Figure S2. Transmission electron microscopy (TEM) image (A) of synthetic hematite NPs (scale

45 bar is $20 \mathrm{~nm}$ ) with the primary particle size of $9 \pm 2 \mathrm{~nm}$ (one standard deviation), as shown in the size distribution diagram (B).The hydrodynamic diameters of the hematite NPs was $125 \pm 18 \mathrm{~nm}$ (one standard deviation) in the solution at $\mathrm{pH} 5.7$ without $\mathrm{NaCl}$. 

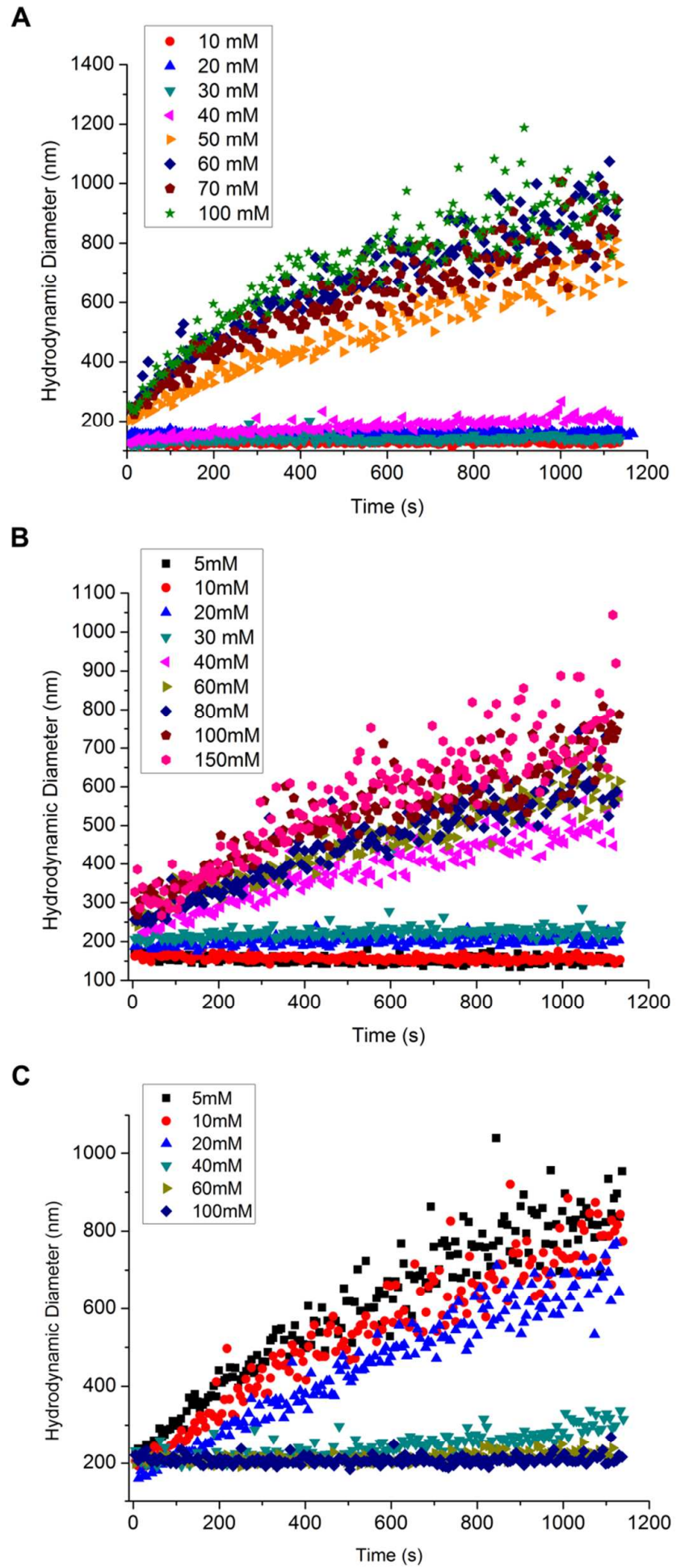

Figure S3 Aggregation profiles of $16 \mathrm{mg} / \mathrm{L}$ bare hematite NPs (A) and NPs in the presence of 8 $\mathrm{mg} / \mathrm{L} \mathrm{Cyt}(\mathrm{B})$ or $\mathrm{BSA}(\mathrm{C})$ at $\mathrm{pH} 5.7$ with varied $\mathrm{NaCl}$ concentrations. 

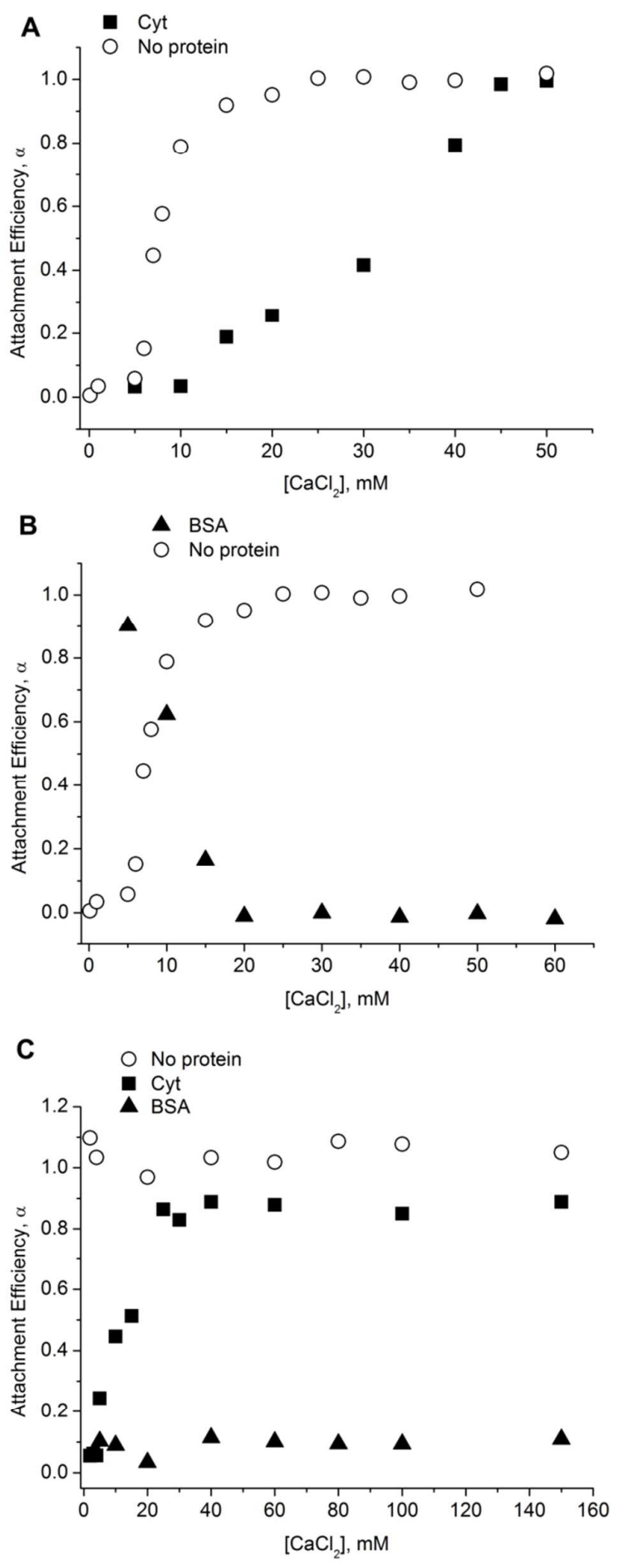

53

Figure S4. Comparison of attachment efficiencies of $16 \mathrm{mg} / \mathrm{L}$ hematite NPs with and without (A) 8 mg/L Cyt at $\mathrm{pH} 5.7$, (B) $8 \mathrm{mg} / \mathrm{L} \mathrm{BSA}$ at $\mathrm{pH} 5.7$, and (C) $8 \mathrm{mg} / \mathrm{L} \mathrm{BSA}$ or Cyt at $\mathrm{pH} 9$ as a function of $\mathrm{CaCl}_{2}$ concentration. 


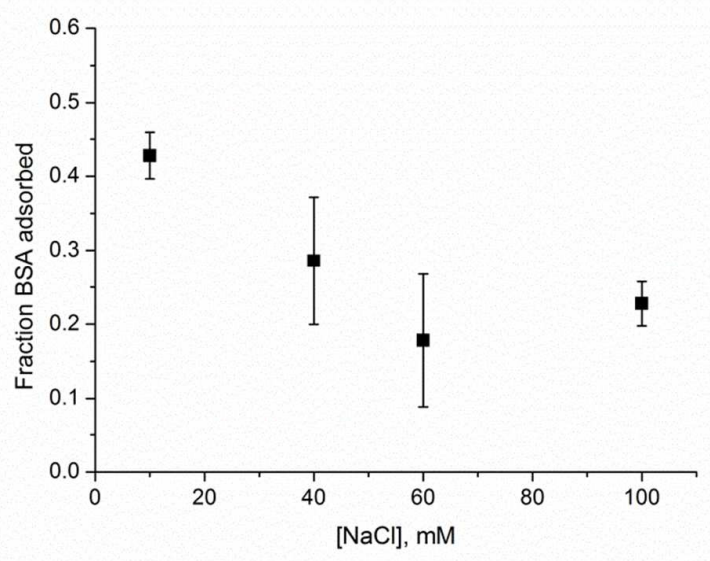

57

58 Figure S5. The fraction of BSA adsorbed on hematite NPs in solution at $\mathrm{pH} 5.7$ as a function of

$59 \mathrm{NaCl}$ concentration. The initial concentration of the BSA solution added was $390 \mathrm{ng} / \mathrm{cm}^{2}$. The

60 error bars represent the standard deviation from triplicates. 

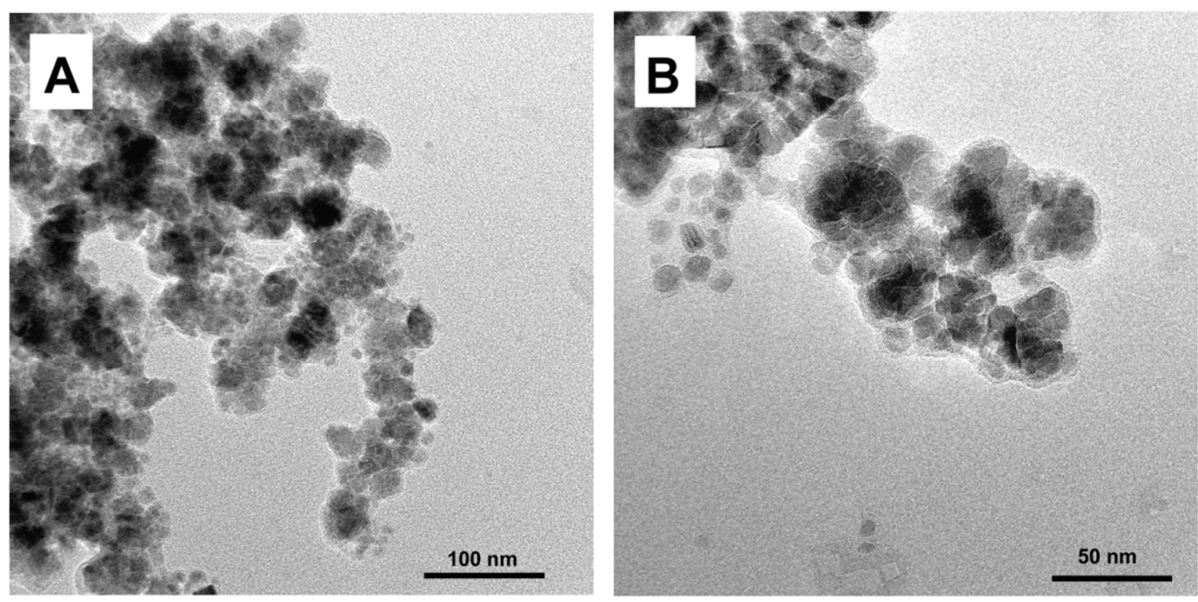

61
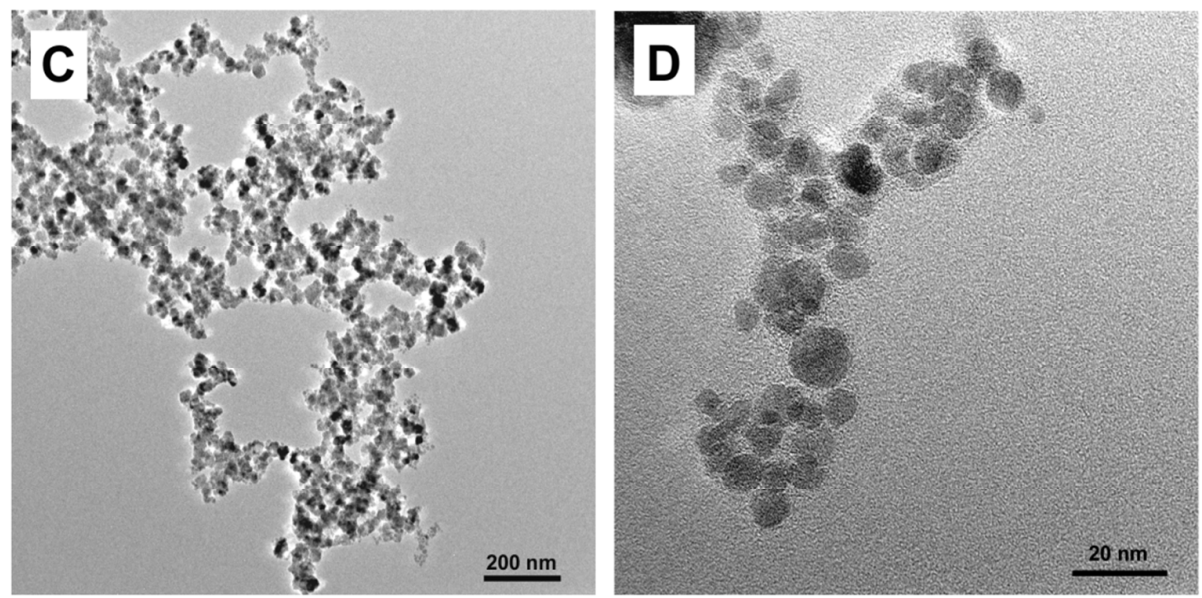

Figure S6. TEM images of hematite NPs with $390 \mathrm{ng} / \mathrm{cm}^{2} \mathrm{BSA}$ in $10 \mathrm{mM} \mathrm{NaCl}$ solution (A and B) and in $80 \mathrm{mM} \mathrm{NaCl}$ solution $(\mathrm{C}$ and $\mathrm{D})$, respectively. A and $\mathrm{C}$ are the images at low magnification to show the overview of the aggregates. $\mathrm{B}$ and $\mathrm{D}$ are the high-magnification images to show the arrangement of NPs in the aggregates.

\section{References:}

1. He, Y. T.; Wan, J. M.; Tokunaga, T., Kinetic stability of hematite nanoparticles: the effect of particle sizes. J Nanopart Res 2008, 10, (2), 321-332.

2. Rezwan, K.; Meier, L. P.; Rezwan, M.; Voros, J.; Textor, M.; Gauckler, L. J., Bovine serum albumin adsorption onto colloidal Al2O3 particles: A new model based on zeta potential and UV-vis measurements. Langmuir 2004, 20, (23), 10055-10061.

3. Salgin, S.; Salgin, U.; Bahadir, S., Zeta Potentials and Isoelectric Points of Biomolecules: The Effects of Ion Types and Ionic Strengths. Int J Electrochem Sc 2012, 7, (12), 12404-12414.

4. Dickerso.Re; Takano, T.; Eisenber.D; Kallai, O. B.; Samson, L.; Cooper, A.; Margolia.E, 
77 Ferricytochrome C.1. General Features of Horse and Bonito Proteins at 2.8 a Resolution. J. Biol. Chem.

78 1971, 246, (5), 1511-\&.

79 5. Eggleston, C. M.; Khare, N.; Lovelace, D. M., Cytochrome c interaction with hematite

80 (alpha-Fe2O3) surfaces. J. Electron Spectrosc. Relat. Phenom. 2006, 150, (2-3), 220-227.

81 